\title{
A COMPARATIVE ANALYSIS OF THE UNCITRAL MODEL LAW ON CROSS-BORDER INSOLVENCY AND EU INSOLVENCY REGULATION 2017, AGAINST THE BACKGROUND OF VARIOUS SOURCES OF CROSS- BORDER INSOLVENCY LAW
}

\author{
by Primrose E.R. Kurasha*
}

\section{Introduction}

In this investigation, I will compare and contrast the UNCITRAL model law on cross-border insolvency law (hereafter referred to as 'UNCITRAL model law') with the EU Insolvency Regulation against the backdrop of various sources or dispensations of cross-border insolvency law. In this comparison, I will highlight the similarities and differences between the two, as well as discuss the other sources in depth, as they largely inform my research. My main aim in including the other sources in this comparative study is to provide deeper insight into these two sources of international cross-border insolvency law, as provided for by academics and sages in the field of insolvency law. These other sources include legislation, common law, treaties and regional dispensations.

\section{Comparative analysis}

\subsection{Definitions}

The term 'insolvency' is not defined in the South African Insolvency Act of 1936 (hereafter referred to as 'the Insolvency Act'). The terms 'insolvent' and 'insolvent estate' are, however, defined as nouns. In terms of section 2 of the Insolvency Act, an 'insolvent' refers to a debtor whose estate is under sequestration, including such a debtor before the sequestration of his estate according to the context. An 'insolvent estate' is simply defined as an estate under sequestration. ${ }^{1}$ Insolvency is ultimately succinctly defined in American case law as 'the condition of a person who is unable to pay his debts as they fall due, or in the usual course of trade and business." 2 Summarily,

\footnotetext{
* BA (Law), LLB, LLM (University of Pretoria) LLM in International Trade and Investment Law in Africa (University of Pretoria).

1 Section 2 of the Insolvency Act 24 of 1936.

2 Dewey $v$ St Albans Trust Co, 56 Vt. 475. 48 Am. Rep. 803.
} 
insolvency law is therefore the law regulating the sequestration of an insolvent debtor. Cross-border insolvency law can be defined as the rules and regulations that administer the treatment of financially distressed debtors if such debtors have assets or creditors in more than one country. ${ }^{3}$ In other words, the nexus between insolvency and cross-border insolvency lies in the fact that in both scenarios there is an insolvent. However, in the case of (domestic) insolvency law, the treatment or sequestration of the insolvent's estate is managed by the relevant local insolvency laws, while in the case where the insolvent owns assets internationally, sequestration of his or her estate will be regulated by laws on cross-border insolvency which are specific to each jurisdiction. Nonetheless, these domestic (or jurisdiction-specific) insolvency laws may indeed be similar to the local laws, as various countries have adopted the UNCITRAL model law into their domestic insolvency legal regime, while the $28 \mathrm{EU}$ member countries have adopted the EU Insolvency Regulation.

In terms of terminology, it is also worth noting that the sequestration of an insolvent's estate can interchangeably mean the liquidation of an insolvent or a bankrupt company.

The UNCITRAL model law is defined as the model law on CrossBorder Insolvency of the United Nations Commission on International Trade Law. It is set out in the Annexure to the United Nations General Assembly Resolution. ${ }^{4}$ The UNCITRAL Model Law does not define 'insolvency', nor does the Insolvency Act. However, the two instruments are similar in their purpose, namely to provide a law that is used to administer the sequestration of an insolvent's estate. The UNCITRAL Model law takes it a notch higher by prescribing a template that is suggested to be used as the common law by the courts of various jurisdictions to administer the sequestration of an insolvent's estate, with automatic recognition of a foreign trustee by a foreign court.

\subsection{Sources}

In principle, the sources of cross-border insolvency law are comprised of legislation, treaties, model laws (such as the UNCITRAL model law), case law, academic opinions, regulations (such as the EU Insolvency Regulation of 2017) and regional dispensations.

It should be noted, however, that the EU Insolvency Regulation of 2000 was amended by the EU Insolvency Regulation of 2017, which came into force on 26 June 2017. As such, in this discussion I shall focus on the EU Insolvency Regulation of 2017.

3 I Fletcher Insolvency in private international law (2005) 3.

4 Model Law on Cross-Border Insolvency of the United Nations Commission on International Trade Law A/RES/52/158 (1997). 


\subsection{Cross-border insolvency law: Motivation and jurisprudence}

As a point of departure, it is necessary to explain the rationale behind the need for cross-border insolvency law.

Cross-border insolvency law was necessitated by the conflict of laws and private international law systems existent in different jurisdictions worldwide. When an insolvent debtor faces claims from many creditors and owns property in various nations, it was (and is still) necessary that the insolvency order by the court of the debtor's so-called 'Centre of Main Interest' (COMI) be made enforceable in these other countries. Cross-border insolvency law is meant to mitigate such conflicts through sources such as the UNCITRAL model law and the EU Insolvency Regulation. These instruments seek to achieve the automatic recognition of foreign estate representatives in different jurisdictions, the inherent enforceability of the insolvency order and the co-operation of the various courts in liquidating the estate of the insolvent debtor and paying his creditors. The foreign estate representative will place an outward bound request before the court of the foreign jurisdiction in order to be recognised and enforce the insolvency order made by the court of the insolvent debtor's COMI.

Moreover, cross-border insolvency law was created to equate the 'playing and claiming field' of foreign and domestic creditors. In his article 'Legal Treatment of Foreign and Domestic Creditors', Nadelmann highlights the challenges faced by creditors in their participation in insolvency claims against insolvent debtors. ${ }^{5}$ The problems he articulates include discriminatory rules in treatment between foreign and domestic creditors, a lack of notification that enables creditors' compliance with procedural requirements, the 'race of diligence', obliging creditors to pursue the execution of judgments and the attachment of claims hurriedly in order to prevent competing interests from acquiring priority. ${ }^{6}$

The rationale behind the publication of the UNCITRAL model law as a source of insolvency law is that if United Nations member states adopt the UNCITRAL model law, then at least amongst those nations, there will be some level of knowledge and predictability in terms of how to go about applying for a recognition order. Furthermore, they will have knowledge on how to open up concurrent proceedings in various jurisdictions that might be involved in the estate of a particular insolvent debtor.

$5 \mathrm{~K}$ Nadelmann Legal treatment of foreign and domestic creditors (1946).

$6 \quad$ Nadelmann (n 5 above) 698. 
In my opinion, the aforementioned legal reasoning behind the creation of various sources of cross-border insolvency law is vital in order to enable one to appreciate the vital role that cross-border insolvency law plays in foreign trade, thus highlighting its significance as an initiative. Furthermore, it aids one in understanding the constant evolution of cross-border insolvency law, as is evidenced by the EU Insolvency Regulation of 2017, which is an improved version of the EU Insolvency Regulation of 2000. The EU Insolvency Regulation of 2017 is a metamorphosis of its predecessor and thus reflects and regulates the modern trends in cross-border insolvency law more effectively. This progression is imperative, especially in a globalised world economy characterised by an open market where an increasing number of people own foreign property and where events such as the Financial Crisis of 2007-2008 may result in the insolvency and bankruptcy of many such foreign property owners. The aforementioned Global Financial Crisis of 2008 subsequently resulted in many claims being filed against insolvents worldwide, a phenomenon that the EU Insolvency Regulation of 2000 inadequately catered for. For instance, the Regulation did not clearly define fundamental concepts such as 'insolvency' or adequately address the requirements of initiating an insolvency procedure across the board. It also failed to sufficiently cater for restructuring and cash-flow issues. These oversights are, however, understandable, as such an economic crisis had not been experienced in the few years preceding the Regulation's conception and it was not necessarily foreseeable in the new millennium. Speaking to these current trends, the new EU Insolvency Regulation of 2017 caters for such cross-border insolvency catastrophes comprehensively.

Having discussed the development of cross-border insolvency law, the next section analyses and evaluates other sources of cross-border insolvency law.

Omar's contribution is instrumental to this discussion. ${ }^{7}$ In his article, 'The Landscape of International Insolvency Law', he discusses the theories of territoriality and universality. ${ }^{8}$ These two theories fall under the insolvency concept of predictability. Universality is an American school of thought which proposes the unity of cross-border insolvency proceedings. It is deemed to be a more successful alternative to territoriality by its protagonists. Consider for example the following illustration of universality:

A debtor named Paul is declared insolvent in South Africa by the Western Cape High Court, as his COMI is Paarl, Cape Town, where he owns vineyards and runs a wine business. Paul has outstanding debts

7 PJ Omar 'The landscape of international insolvency law' (2002) 11 International Insolvency Review 1.

8 Omar (n 7 above) 176. 
with many different creditors. Paul also owns numerous other properties in 20 different countries, each with their own domestic insolvency laws. It logically follows that Paul's estate representative, Victor, must travel abroad to these various jurisdictions to sell these properties in order to pay off Paul's creditors with the proceeds thereof. However, Victor will need recognition as a foreign estate representative in each of the 20 different courts, which is time consuming.

The universality theory involves the unity of proceedings and holds that the South African law of insolvency should be applicable in each of the 20 other jurisdictions. In other words, the South African insolvency law is the law that must be applied during the main sequestration proceeding.

On the other hand, territoriality is a notion that demands the recognition of a foreign estate representative by the courts of a foreign jurisdiction in order to enable the enforceability of a foreign insolvency order against a debtor in a foreign nation in which an insolvent owns property. ${ }^{9}$ If territoriality is applied to the above scenario, in order to gain recognition as a foreign estate representative in each of the countries, territoriality would require Victor to go and file for recognition proceedings (called outward bound requests), in the insolvency courts of each of the 20 jurisdictions. This principle was applied by the South African Supreme Court of Appeal (hereafter 'the SCA') in the case of Lagoon Beach Hotel $v$ Lehane. ${ }^{10}$ In this case, the SCA considered granting a preservation order to a foreign trustee and, in exceptional circumstances, recognition of a foreign trustee. A further example of territoriality in cross-border insolvency is found in the American case of Maxwell Communication Corp, Societe Generale (In re Maxwell Communication Corp) as decided by the US Court of Appeals. ${ }^{11}$ This case is the lex classicus of cross-border insolvency, as it concretised the principle of co-operation between foreign courts in cases of crossborder insolvency. In this case, a media empire was headquartered in England with its subsidiaries and assets spread across the United Kingdom, the United States of America and Canada. As a result, a number of legal regimes was applicable to various aspects of the cross-border insolvency dispute, as determined by the various lex loci of the assets of the insolvent company. It is for this reason that territoriality was evident in the case.

The disadvantage of universality is the fact that it threatens the sovereignty of countries. This is the main reason many legal

9 Omar (n 7 above) 176

10 (235/2015) [2015] ZA SCA 2010 (21 December 2015).

11 Maxwell Communication Corp, Societe Generale (In re Maxwell Communication Corp) 93 F.3d 1036 (2d Cir. 1996). 
jurisdictions' apathy towards universality. It is seen to be offensive to apply South African insolvency laws and impose its legal notions within other jurisdictions and their courts. Furthermore, universality demands a high level of reciprocity in terms of intergovernmental and interstate co-operation. This is problematic due to the lack of trust that often exists between many states. Territoriality is therefore a better alternative from a political perspective.

Be that as it may, territoriality is not without flaws either in my opinion. Firstly, territoriality may lead to a situation where we would ultimately run out of options with regard to international laws on claiming against an insolvent. Secondly, the territoriality theory has negative consequences from an economic perspective. If many different concurrent insolvency proceedings are initiated, different foreign estate representatives will have to be appointed in each of the domestic jurisdictions. As such, this insolvency proceedings can become more expensive and complex. Inevitably, those appointed as foreign estate representatives will charge their own fees towards the estate and this will diminish the assets or proceeds that actually go to the creditors. Whilst this might be justified (or made up for) by the fact that there are assets that are to be realised in these countries, financial maximisation is not guaranteed.

In light of such of a dilemma, the phenomenon of concurrent jurisdiction has been hatched as a pragmatic solution by the courts and legislatures of various countries such as France and Germany. In terms of concurrent legislation, in the above example the insolvency order against Paul as an insolvent will be enforceable in all other jurisdictions without a need for Victor, Paul's foreign estate representative, to apply for recognition in all 20 foreign jurisdictions. The principle behind concurrent jurisdiction is that of comity, ${ }^{12}$ which fosters the co-operation of courts in different jurisdictions in crossborder insolvency law.

It is in this spirit of co-operation and in accordance with this principle of comity that the sources of cross-border insolvency law, such as the UNCITRAL model law and the EU Insolvency Regulation, are modelled. The UNCITRAL model law is a legislative framework that a country may choose to incorporate into its legislation. When incorporated, it outlines when that country's domestic courts should recognise foreign insolvency proceedings. ${ }^{13}$ Having granted such recognition, the court may then provide particular assistance to the foreign estate representative. The UNCITRAL model law does not

12 BE Leonard \& CW Besant Current issues in cross-border insolvency and reorganisation (1994).

13 Thomson Reuters Practical Law 'UNCITRAL Model Law on Cross-Border Insolvency' February 2017 https://uk.practicallaw.thomsonreuters.com/0-502-6976?transi tionType $=$ Default\&contextData $=(\mathrm{sc}$. Default $) \&$ firstPage $=$ true\&bhcp $=1 \quad($ accessed 28 June 2017). 
therefore seek to unify insolvency law across all borders, as any nation can choose whether or not to adopt it. ${ }^{14}$ The EU Insolvency Regulation establishes a common legal framework for EU insolvency proceedings. ${ }^{15}$ It establishes the common rules for a court that is competent to open insolvency proceedings, the applicable law and the recognition of the decisions of the court upon the debtor's insolvency. ${ }^{16}$ Like the UNCITRAL model law, the EU Insolvency Regulation does not seek to harmonise insolvency law in the EU.

Ultimately, it is in light of this background that the cross-border insolvency law schools of thought, being territoriality and universality, led to the conception and birth of more harmonised and integrated sources of cross-border insolvency law in the forms of the UNCITRAL model law and EU Insolvency Regulation.

Chapter 15 of the American Bankruptcy Code of 1978 ('the American Bankruptcy Code') is an example of the UNCITRAL model law being adopted into local legislation. It thus brought the UNCITRAL model law into force in the United States of America (the USA). Summarily, Chapter 15 enables a foreign estate representative of a foreign insolvency proceeding (which took place outside of the USA) to gain access to American courts. Chapter 15 provides for cooperation between American courts and foreign courts, as well as other authorities of foreign jurisdictions that participate in crossborder insolvency cases. In other words, the USA is a good example of a major jurisdiction that has adopted the UNCITRAL model law into its legislation.

The Australian Cross-border Insolvency Act of 2008 is a further example of the UNCITRAL model law being adopted into local legislation. It is akin to Chapter 15 of the American Bankruptcy Code, as both pieces of legislation are based on the UNCITRAL model law. Article 13 of the Australian Cross-border Insolvency Act of 2008 provides for the recognition of a foreign estate representative in the Australian jurisdiction and the subsequent enforcement of the foreign insolvency order.

Section 426 of the English Insolvency Act of 1986, which provides for assistance and recognition of foreign estate representatives seeking to enforce insolvency orders in its jurisdiction, is an imitation of a fully developed cross-border insolvency statute nonetheless, which applies to a smaller scale, i.e. domestically. This is due to the fact that it only applies to certain designated countries, excluding some key global players in trade such as the USA. The designated countries are Anguilla, Australia, the Bahamas, Bermuda, Botswana,

14 Thomson Reuters (n 13 above).

15 European Commission 'Insolvency proceedings' http://ec.europa.eu/justice/ civil/commercial/insolvency/index_en.htm (accessed 28 June 2017).

16 European Commission (n 15 above). 
Brunei, Canada, Cayman Islands, Falkland Islands, Guernsey (modified), Gibraltar, Hong Kong, the Republic of Ireland, Malaysia, Montserrat, New Zealand, South Africa, St Helena, Turks and Caicos Islands, Tuvalu and the Virgin Islands.

Nevertheless, the English Cross-border Insolvency Regulation of 2006 (hereafter 'the CBIR of 2006') applies to the non-designated states. The CBIR of 2006 therefore seeks to bridge the gap created by the aforementioned Act and facilitates a more efficient cross-border insolvency law by recognising those once excluded foreign estate representatives of foreign insolvency proceedings that took place in non-designated countries.

Among the international instruments, the UNCITRAL model law has become a popular source of cross-border insolvency law in the sense that it is a legal framework against which many national laws are being developed and reformulated. ${ }^{17}$ South Africa is a case in point. The South African Insolvency Act enforces South African insolvency law only and is therefore not a source of cross-border insolvency law. Such cases of entrenched domestic laws have stifled the harmonisation of insolvency laws in Southern Africa as a region. Nonetheless, the South African judiciary and legislature have made progressive attempts to reframe a new South African Insolvency Act that is based on the UNCITRAL model law, in order to facilitate harmonisation and co-operation of cross-border insolvency law in Southern Africa and eventually Africa as a whole. ${ }^{18}$

The OHADA Treaty (signed on 17 October 1993) is also a source of cross-border insolvency law. It binds the majority of Francophone African countries to the same trade practices, including cross-border insolvency law and enforcement thereof, across the Francophone African terrain.

Having explained some of the sources of cross-border insolvency law globally, the next section compares the UNCITRAL model law with the EU Insolvency Regulation.

\subsection{Comparison between the UNCITRAL model law of insolvency and the EU Insolvency Regulation}

The UNCITRAL model law is not binding, as it is merely a template and framework that countries may choose to adopt and incorporate into

17 UNCITRAL 'UNCITRAL Model Law on International Commercial Arbitration (1985), with amendments as adopted in 2006' January 2017 http://www.uncitral.org/ uncitral/en/uncitral_texts/arbitration/1985Model_arbitration.html (accessed 28 June 2017).

18 'Model Law Adapted for Enactment in South Africa: Annexure B' http://www. justice.gov.za/salrc/media/1998_crossbannexb.pdf (accessed on 9 November 2017). 
their domestic insolvency laws. An apt illustration is the incorporation of the UNCITRAL model law into the American Bankruptcy Code in the form of Chapter 15, as previously discussed.

A similarity between the UNCITRAL model law and the EU Insolvency Regulation is the purpose that each serves. The EU Insolvency Regulation is not in place to harmonise substantive insolvency law, because it has no bearing on sections of national insolvency law. It is a private international law instrument seeking to promote a solution to conflicts of jurisdictions and applicable law. For instance, it prescribes the applicable law for finding an answer to a legal question in a particular case. The applicable law may be the law of the country where the insolvency proceedings were opened. It is then left to that national insolvency law to determine the outcome of the legal issue. The EU Insolvency Regulation will not override that national insolvency law, as it just points to the applicable national law that one should look at in order to find the answer to the legal issue or question at hand.

Similarly, the UNCITRAL model law rules do not harmonise the national insolvency laws of the different jurisdictions that adopt it. It does not alter the intrinsic insolvency law principles of the various jurisdictions of the countries that adopt it and each country maintains its own sovereignty regarding national insolvency laws. For example, South Africa still has the Insolvency Act of 1936 and England still has the Insolvency Act of 1986, despite having adopted the UNCITRAL model law for enactment in South Africa. This reinforces the idea that the UNCITRAL model law serves only as a template for a predictable procedure that a foreign estate representative can use in order to apply for recognition or to open up concurrent insolvency proceedings in a foreign jurisdiction.

The UNCITRAL model of law and the EU Insolvency Regulation differ with regard to the application of recognition. The UNCITRAL model law provides for assistance to a foreign estate representative in approaching the court to request recognition for his proceeding. ${ }^{19}$

Under the EU Insolvency Regulation, recognition is automatic. ${ }^{20}$ The foreign estate representative does not need to apply for recognition of his insolvency proceeding in another EU jurisdiction. As soon as an insolvency proceeding has been opened in, for example, the Netherlands, it is also effective in all other EU member states and no prior court application or publicity is required. The fact that a

19 Thomson Reuters Practical Law 'UNCITRAL model law on cross-border insolvency' February 2017 https://uk.practicallaw.thomsonreuters.com/0-502-6976?transi tionType $=$ Default\&contextData $=($ sc. Default $) \&$ firstPage $=$ true\&bhcp $=1 \quad($ accessed 28 June 2017).

20 INSOL Europe Proposals by INSOL Europe: Revision of the European Insolvency Regulation (2011) 21. 
Dutch judgment opening insolvency proceedings against an insolvent debtor with assets in Italy, has not been published in Italy, does not alter the fact that the effects of the Dutch insolvency proceedings apply in Italy from the moment that they are effective in the Netherlands. This request for recognition is another conceptual difference that exists between the UNCITRAL model law and the EU Insolvency Recognition.

A similarity between the UNCITRAL model law and the EU Insolvency Regulation is the fact that they are both centred on the concept of a COMI and the establishment of grounding jurisdiction of two types, namely main and secondary proceedings. According to the EU Insolvency Regulation jargon, the main and secondary proceedings are referred as the 'main' and 'secondary proceedings' whilst on the other hand, the UNITRAL model law calls it the 'main' and the 'nonmain' proceedings.

However, a difference between the UNCITRAL model law and the EU Insolvency Regulation is their respective spheres of influence. The UNCITRAL model law is a suggested (hence non-binding) legal framework for the cross-border insolvency system of any UN member state wishing to follow it, while the EU Insolvency Regulation is a binding cross-border insolvency law on the $28 \mathrm{EU}$ member states only.

A further subtle similarity exists between the EU Insolvency Regulation and the UNCITRAL Model Law. According to Omar, the EU Insolvency Regulation is characterised by a 'constellation' paradigm striving to establish a hierarchy and coordination between proceedings that involve the same debtor, while a similar but lighter structure is prevalent within the UNCITRAL model law. ${ }^{21}$

\section{Conclusion}

In conclusion, the above comparison between the UNCITRAL model law and the EU Regulation highlights a common aim of easing the liquidation process of an insolvent for the aggrieved creditors. This is done with the ultimate goal of providing justice to creditors by paying to them the insolvent's debts.

It is apparent that cross-border insolvency law mitigates the complexities of extra-jurisdictional insolvency proceedings through provisions that encourage co-operation between states. The EU Insolvency Regulation provisions, for example, encourage concurrent jurisdictional insolvency proceedings that ameliorate burdensome legal applications, such as the outward bound requests of foreign estate representatives seeking recognition. Summarily, predictability 
is established by these sources of cross-border insolvency law through such provisions. It is in this predictability that the beauty of crossborder insolvency law lies, as predictability and legal certainty fosters international trade through the security of business and investments. Be that as it may, this beauty will not be fully realised if countries do not adopt the UNCITRAL model law. Furthermore, in the case of Europe, the positive far-reaching effect of the EU Insolvency Regulation is limited by the fact that only 28 European states can enjoy the ease of concurrent insolvency proceedings. However, the further evolution of cross-border insolvency law should increasingly fill these legal fissures. 